\title{
Role of Pigeonpea Cultivation on Soil Fertility and Farming System Sustainability in Ghana
}

\author{
S. Adjei-Nsiah \\ Forest and Horticultural Crops Research Centre, Kade, Institute of Agricultural Research, College of Agriculture and Consumer Sciences, \\ University of Ghana, P.O. Box 68, Legon, Ghana \\ Correspondence should be addressed to S. Adjei-Nsiah, y_nsiah@yahoo.co.uk
}

Received 19 March 2012; Revised 6 June 2012; Accepted 8 June 2012

Academic Editor: Antonio M. De Ron

Copyright (๑) 2012 S. Adjei-Nsiah. This is an open access article distributed under the Creative Commons Attribution License, which permits unrestricted use, distribution, and reproduction in any medium, provided the original work is properly cited.

The productivity of the smallholder farming system in Ghana is under threat due to soil fertility decline. Mineral fertilizer is sparingly being used by smallholder farmers because of prohibitive cost. Grain legumes such as pigeonpea can play a complementary or alternative role as a source of organic fertilizer due to its ability to enhance soil fertility. Despite its importance, the potential of pigeonpea as a soil fertility improvement crop has not been exploited to any appreciable extent and the amount of land cultivated to pigeonpea in Ghana is vey negligible. This paper synthesizes recent studies that have been carried out on pigeonpea in Ghana and discusses the role of pigeonpea cultivation in soil fertility management and its implication for farming system sustainability. The paper shows that recent field studies conducted in both the semi-deciduous forest and the forest/savanna transitional agroecological zones of Ghana indicate that pigeonpea/maize rotations can increase maize yield by $75-200 \%$. Barrier to widespread adoption of pigeonpea include land tenure, market, and accessibility to early maturing and high yielding varieties. The paper concludes among other things that in order to promote the cultivation of pigeonpea in Ghana, there is the need to introduce varieties that combine early maturity with high yields and other desirable traits based on farmers preferences.

\section{Introduction}

Agricultural productivity in the smallholder farming systems in Ghana is under threat due to declining soil fertility. In the past, smallholder farmers in Ghana relied on the extended bush fallow system for maintaining the productivity of their farmlands [1]. This system allowed restoration of phosphorus $(\mathrm{P})$ and nitrogen $(\mathrm{N})$, the most limiting nutrients. However, over the years, the population growth-induced scarcity of suitable farmland has led to the shortening of the fallow period making it difficult to manage soil fertility in smallholder farming systems. The problem is compounded by the increasing cost of inputs at the farm level due to structural adjustment programmes that have removed subsidies and increased supply costs due to the deterioration conditions of rural infrastructure [2]. For instance, in 2002, whereas a metric tonne of urea cost about US\$90 FOB (free on board) in Europe [3], the same quantity cost a Ghanaian farmer about US $\$ 308$ at the farm level [4].
Most farmers, especially the smallholder farmers, do not have access to formal credit and therefore cannot afford to buy mineral fertilizers even when it has been demonstrated to be profitable [5]. Furthermore, due to the unpredictability of rainfall in some areas, farmers consider fertilizer application as risky.

In smallholder farming systems in Ghana, legumes can play a complementary or alternative role as source of organic fertilizer. Research in many parts of Sub-Saharan Africa including Ghana has shown that legumes have the potential to sustain soil fertility in smallholder farming systems [68]. Pigeonpea (Cajanus cajan (L.) Millsp.) has been found to have a great potential in this respect because of its ability to recycle nutrients and tolerate wide environmental conditions and low soil fertility [9]. Pigeonpea is nutritionally well balanced and is an excellent source of proteins (20-30\%) [7]. In addition to proteins, pigeonpea provides carbohydrates and high levels of vitamins A and C. 
Despite the importance of pigeonpea in terms of nutrition and soil fertility improvement, the crop has not been promoted to any appreciable extent by the national agricultural research and extension system in Ghana. In the forest/ savannah transitional zone where the crop is widely cultivated, pigeonpea is considered as women's crop and therefore minor due to men's dominion over women in household decision-making process. Furthermore the overemphasis on maize in the current production systems as the major food security and cash crop in the forest/savanna transitional zone has relegated pigeonpea in particular and legumes in general as a minor crop.

However, recent studies in the forest/savannah transitional agroecological zone as well as the semideciduous forest zone of Ghana have demonstrated that when integrated in the cropping system as a form of rotation, pigeonpea has the potential of improving soil fertility. This paper discusses the role of pigeonpea cultivation in soil fertility management and its implication for farming system sustainability and food security.

\section{Material and Methods}

This paper is largely based on studies that have been conducted in the forest/savannah transitional agro-ecological zone of Ghana between 2002 and 2006 under the framework of Convergence of Science project [10] and between 2007 and 2010 under the IDRC funded Climate Change Adaption programme in Africa [11]. Results from the 2002-2006 studies have already been published $[8,9,12]$, while results from 2007-2010 studies have not been published.

2.1. The Study Area and Population. The studies were conducted in the Wenchi Municipal $\left(7^{\circ} 27\right.$ and $8^{\circ} 30 \mathrm{~N}, 1^{\circ}$ and $2^{\circ} 36 \mathrm{~W}$ ) in the forest/savanna transitional agro-ecological zone of Ghana. The relief of Wenchi is gently undulating to flat. The soils, which are mainly Lixisols, are fragile with shallow top soils underlain with compact concretions and impermeable iron pans [8]. Temperatures are relatively high with a monthly mean of about $30^{\circ} \mathrm{C}$. Rainfall is bimodal and starts in April and ends in November with a dry spell in August. The rainy season is followed by a long dry season from November to March. The annual rainfall is about $1,300 \mathrm{~mm}$ with about 107 rainy days. Wenchi municipal, which has a total population of 97,058 (2000 census), is ethnically diverse with about $20 \%$ of the population being migrants from the three northern regions of Ghana and the neighbouring Burkina Faso.

2.2. Research Approach and Methods. In 2002, we carried out a study under the Convergence of Sciences project to explore farmers' soil fertility management strategies and their relevant social context [8]. In order to ground the research in the needs of the farming communities, a diagnostic study was carried out in the study area between July, 2002 and July, 2003 using Participatory Rural Appraisal tools such as drawing of a community territory map (to identify the differences in soil fertility patterns), a transect walk (to reveal the diversity of the landscape), and analysis of soil fertility management strategies and group discussions. Group discussions with 1040 farmers were held in the village centre and/or on farmers' fields.

In addition, two sets of individual interviews with farmers were conducted to collect qualitative and quantitative data. In the first interview, which involved 40 farmers, the selection of farmers was done through stratified sampling. A list of farmers in the community was obtained from the village committee secretary and every tenth name from the list was selected for individual interviewing. The second interview which involved 38 farmers was conducted later to look at the farming characteristics of the various subcommunities in the village using a wealth ranking exercise. For this interview, 6-10 persons were selected from each wealth category within each subcommunity. The individual interviews were semistructured in nature and served both to get more quantitative data on farm size, household composition, and the farming system and to obtain a better qualitative understanding of the soil fertility management strategies and their underlying rationale.

The diagnostic study was followed by farmer participatory on-farm experimentations with three farmer research groups established soon after the diagnostic study to evaluate the agronomic efficacy of the soil fertility mana-gement practices being used by the farmers [9]. Six cropping sequences: cassava cropping; pigeonpea cropping; mucuna/ maize/mucuna rotation; cowpea/maize/cowpea rotation; maize/maize/maize; Imperata cylindrica fallow were evaluated on both farmer-managed and researcher-managed plots for their effects on soil fertility and yield of subsequent maize test crop. To deepen our understanding of soil fertility management, we carried out further exploration of diversity among the farmers according to gender, ethnicity, and wealth [12]. Farmers were selected from three communities in Wenchi according to ethnicity and gender for interview using semistructured questionnaires. We conducted two sets of interviews. For the first interview, the native households were categorized into male-headed and female-headed households. Subsequently, a stratified sample was selected consisting of 20 males from male-headed households, 20 females from male-headed households, and 20 females from femaleheaded households. In the case of the migrants, every farmer in the community was interviewed because of the small size of their population. As migrant women do not have their own farming enterprises, only males were interviewed. In the second interview, the farmers were selected through a wealth ranking exercise. Fifteen farmers were selected from each of three wealth categories for interviewing. In addition, focus group discussions were held with chiefs, community leaders, family heads, and opinion leaders about land tenure systems in Wenchi.

In 2008, under the IDRC, funded climate change adaptation in Africa project, farmers evaluated three early maturing and three late maturing pigeonpea varieties obtained from the International Crop Research Institute of the Semi-Arid Tropics (ICRISAT) in India, in a community in Wenchi called Asuoano. 


\section{Results and Discussion}

3.1. Farmers Views on Soil Fertility Decline and Their Causes. Farmers used several terms to express the fertility status of their soils although the terminology differed from one ethnic group to another. For instance, among the Akans and the Walas, when the soil loses its fertility, the farmers would say the soil is "tired" and therefore must be allowed to "rest" under bush fallow to regain its lost "energy." Farmers used various indicators such as colour, water holding capacity, and soil texture to assess soil fertility. A black soil was considered fertile while gravelly and sandy soils were considered less fertile. Other indicators used by farmers to express soil fertility included presence of earthworm casts which the farmers call "earth worm faeces," growth of crops, decline in crop yield and proliferation of certain plant species and weeds. For instance, the presence of weeds like chromolaena odorata and elephant grass (Pennisetum purpureum) indicated a fertile soil while the presence of weeds like spear grass (Imperata cylindrica) indicated a less fertile soil.

Farmers pointed out five major factors as being responsible for soil fertility decline in the area as follows: (1) increasing population as a result of migration of people into the area leading to smaller farms, which has resulted in the continuous cropping of the same piece of land over a long period; (2) annual bushfires which destroy vegetation and the population of earthworms that contribute to soil fertility improvement; (3) monocropping of maize without rotating it with any other crop; (4) the rapid increase in the monetary value of land; (5) felling of trees which exposes the land to the direct action of the sun.

3.2. Commonly Grown Crops in the Area. Table 1 shows the major food crops and grain legumes grown in the area. In terms of magnitude, maize was the most important food crop grown in Asuano. Other food crops included cassava, yams, cocoyam, and plantain. Legumes also played important role in the cropping systems in the area. Farmers listed about seven different types of legumes they cultivated (Table 1). In terms of proportion of land allocated to legumes, farmers ranked cowpea as the most important legume, followed by groundnut and pigeonpea. However, the type of legumes cultivated by farmers differed among the natives and the migrants. While the native farmers preferred pigeonpea, the migrant farmers preferred cowpea and groundnut. This was related to dynamics around land tenure. In Wenchi area, migrants do not own land but access land for farming through share cropping and land renting arrangements and hence preferred short duration legumes like cowpea and groundnut. Long duration legume such as pigeonpea was therefore not a preferred option for migrant farmers. Moreover, the market for pigeonpea is not well developed as it is a local food crop. It must be noted that the sum of the percentage number of people cultivating the various food crops added up to more than $100 \%$ because some farmers cultivated more than one crop since smallholder farmers in Ghana in general and Wenchi in particular practise mixed cropping. Yam was planted on mounds to increase the volume of soil for the development of tubers. Maize,
TABLE 1: The most important food crops and proportion of land allocated to leguminous crops by native and migrant farmers in Asuoano in 2002.

\begin{tabular}{lcc}
\hline & Natives & Migrants \\
& & $\%$ \\
\hline Food crop & & \\
$\quad$ Maize & 100 & 100 \\
Cassava & 100 & 88 \\
Yam & 100 & 94 \\
Cocoyam & 91 & 19 \\
Plantain & 32 & 0 \\
\hline Leguminous crop & & \\
Pigeonpea & 50 & 0 \\
Groundnut & 20 & 35 \\
Cowpea & 10 & 50 \\
White kidney bean & 10 & 0 \\
Bambara groundnut & 5 & 15 \\
Mucuna & 2 & 0 \\
Others & 3 & \\
\hline
\end{tabular}

Source: [8].

cocoyam, and cassava were usually planted on the lower portions of the yam mounds while pigeonpea was planted in the rows between the yam mounds in a sequential order for efficient utilization of nutrients. Yam was usually planted first followed by maize, cocoyam, cassava, and lastly pigeonpea. The legumes mainly cowpea, groundnuts, and pigeonpea were grown to serve several purposes. These included (1) household food security; (2) household income; (3) soil fertility improvement through build up of soil organic matter and release of nutrients, particularly $\mathrm{N}$ for subsequent crops. Where crop rotation involving these legumes and maize was practised, crop succession was planned such that maize was planted after harvesting the legume to take advantage of the nitrogen fixed by the legume. In this way, it helped to either reduce or avoid the use of nitrogen fertilizers which may increase the cost of production.

3.3. Role of Pigeonpea in the Cropping Systems in Wenchi. Among the legumes cultivated by the natives, pigeonpea was grown on a larger scale in comparison with other legumes because of its ability to regenerate soil fertility, its low production cost, its tolerance to pests and diseases, its cash income, and its food value. It was generally grown on less fertile land and land with problematic weeds such as spear grass (Imperata cylindrica).

After cropping a piece of land to crops like maize, cassava, and yam for about three to four years, farmers intercropped their food crops with pigeonpea during the last cropping year of the cycle. After harvesting the component crops, farmers allowed the land to remain under pigeonpea for 18-24 months after which the pigeonpea plants were cut down, burnt and the land cropped to maize or yams. The pigeonpea canopy was perceived to protect the soil from the direct action of the sun and therefore prevents the soil from becoming hardened. According to the farmers, pigeonpea 
TABLE 2: Effect of crop sequence and $\mathrm{N}$ rate on (a) maize grain yield $\left(\mathrm{kg} \mathrm{ha}^{-1}\right)$ and (b) weed biomass $\left(\mathrm{kg} \mathrm{ha}^{-1}\right)$ associated with the maize crop at 8 weeks after planting on researcher-managed plots.

(a)

\begin{tabular}{lccc}
\hline Crop sequence & \multicolumn{2}{c}{$\mathrm{N} \mathrm{rate}\left(\mathrm{kg} \mathrm{ha}^{-1}\right)$} & Mean \\
\hline Speargrass fallow & 1050 & 60 & \\
Cassava & 3002 & 2848 & 1949 \\
Pigeonpea & 2422 & 2972 & 2870 \\
Cowpea-maize-cowpea & 1670 & 2328 & 2697 \\
Mucuna-maize-mucuna & 2970 & 4195 & 3599 \\
Maize-maize-maize & 1380 & 2128 & 1754 \\
\hline Mean & 2082 & 2868 & \\
\hline
\end{tabular}

SED: crop sequence $(\mathrm{CS})=318.4 ; \mathrm{N}$ rate $(\mathrm{NR})=115.3 ; \mathrm{CS} \times \mathrm{NR}=375.8$. $\mathrm{P}<\mathrm{F}: \mathrm{CS}=0.001 ; \mathrm{NR}=0.001 ; \mathrm{CS} \times \mathrm{NR}=0.01$.

Source [9].

(b)

\begin{tabular}{lccc}
\hline \multirow{2}{*}{ Crop sequence } & \multicolumn{2}{c}{$\mathrm{N}$ rate $\left(\mathrm{kg} \mathrm{ha}^{-1}\right)$} & Mean \\
\hline Speargrass fallow & $\mathrm{O}$ & 60 & 686 \\
Cassava & 270 & 790 & 285 \\
Pigeonpea & 390 & 500 & 445 \\
Cowpea-maize-cowpea & 325 & 395 & 360 \\
Mucuna-maize-mucuna & 300 & 345 & 323 \\
Maize-maize-maize & 240 & 430 & 335 \\
\hline Mean & 351 & 460 & \\
\hline
\end{tabular}

SED: crop sequence $(\mathrm{CS})=65.9 ; \mathrm{N}$ rate $(\mathrm{NR})=52.4 ; \mathrm{CS} \times \mathrm{NR}=112.1$. $\mathrm{P}<\mathrm{F}: \mathrm{CS}=0.001 ; \mathrm{NR}=0.05 ; \mathrm{CS} \times \mathrm{NR}=\mathrm{NS}$.

Source [9].

forms a canopy after one year and shades out obnoxious weeds by suppressing their growth. The farmers also explained that the leaf litter covers the soil, reduces soil erosion, improves infiltration, prevents heating of the soil, and enhances earthworm activity. Crops grown on the land after pigeonpea, and especially maize, were perceived by the farmers to look greener, grow faster, and yield more. Rotations involving pigeonpea was often regarded by farmers as a long-term soil fertility management strategy. Despites its importance, migrant farmers preferred to use mainly shortterm strategies such as mounding and the planting of short duration leguminous crops such as cowpea and groundnut for maintaining soil fertility because of the dynamics surrounding land tenure.

3.4. Agronomic Potential of Pigeonpea. Studies in Wenchi and Kade in the forest/savanna transitional and semideciduous forest zones of Ghana, respectively, indicate the potential of pigeonpea in improving soil fertility and farm profitability (Tables 2 and 3 ). In the transitional zone, rotating pigeonpea with maize resulted in about $75 \%$ increase in maize yield over the continuous maize control. In the semi-deciduous forest zone of Ghana, including pigeonpea in the cropping system also resulted in about 100-200\% increase in maize grain yield over continuous maize. In the transitional zone, pigeonpea yielded about 25.5 tons of shoot biomass within 16 months
TABLE 3: Effect of crop sequence on maize grain yield at $12 \%$ moisture content.

\begin{tabular}{lcc}
\hline \multirow{2}{*}{ Crop sequence } & \multicolumn{2}{c}{ Maize grain yield $\left(\mathrm{t} \mathrm{ha}^{-1}\right)$} \\
& $2007 / 2008$ & $2008 / 2009$ \\
\hline Pigeonpea & 7.0 & 2.3 \\
Ex-Subi & 4.6 & 1.9 \\
Boakentemma & 3.5 & 1.4 \\
Cowpea-Maize-Cowpea & 3.0 & 1.5 \\
Groundnut-Maize-Groundnut & 2.7 & 1.6 \\
Maize-Maize-Maize & 2.3 & 1.3 \\
LSD at 5\% & 1.4 & 0.58 \\
\hline
\end{tabular}

Source [13].

of crop growth. High amounts of leaf litters of up to about $2 \mathrm{t} \mathrm{ha}^{-1}$ in one season could be considered a potential source of nutrients for subsequent crop as confirmed by a $75 \%$ increase in maize yield in the transitional zone and up to $200 \%$ increase in maize yield in the semi-deciduous forest zone of Ghana.

Higher maize yield under legume-maize rotation is expected since legumes are known to fix nitrogen, thereby improving the soil nitrogen economy and enhancing the growth of subsequent crop $[6,14,15]$. The higher maize grain yield associated with pigeonpea could largely be attributed to the large amounts of recycled $\mathrm{N}$ incorporated into the soil just before planting the maize test crops. The vigorous root system of pigeonpea has the capacity to explore large soil volume and recycles nutrients from deeper soil profiles. The faster decomposition of the biomass of pigeonpea and $\mathrm{N}$ release compared with that of maize stover was better synchronized with maize demand than the slower release of $\mathrm{N}$ by the poorer quality materials like maize stover. The $\mathrm{N}$ release patterns of organic residues of differential quality have been discussed extensively by $[16,17]$. According to $[16,17]$, poor quality organic residues, with high $C: N$ ratio, provide abundant supply of $\mathrm{C}$ for microbial growth leading to immobilization of soil $\mathrm{N}$ in the microbial biomass. Residues of high quality organic inputs on the other hand decompose quickly and may release about $70 \%$ of the $\mathrm{N}$ within a season under tropical conditions [18].

Besides the beneficial effect of pigeonpea on subsequent maize crops as a result of the high $\mathrm{N}$ recycling properties of the pigeonpea, the role of other nutrients cannot be ruled out. In some studies, increased soil $\mathrm{P}$ availability under pigeonpea was attributed to the efficient solubilisation and uptake of $\mathrm{P}$ from bound sources (e.g., Fe-P) by root exudates [19]. Benefit/cost analysis of different cropping sequences involving three grain legumes and cassava over four cropping seasons indicated that pigeonpea/maize rotations had $108 \%$ return on investment compared with $31 \%$ by continuous maize when fertilizer was not applied to the maize crop (Table 4).

3.5. Challenges in the Cultivation of Pigeonpea. Barrier to widespread adoption of pigeonpea include land tenure, market, and availability of early maturing varieties. In the 
TABLE 4: Estimated costs of production, gross revenue, and returns on investment of (a) various crop sequences (b) maize grown after the sequences with $\mathrm{N}$ application to the maize and (c) maize grown after the sequences without $\mathrm{N}$ application to the maize.

\begin{tabular}{|c|c|c|c|c|c|c|c|c|}
\hline \multirow{2}{*}{ Crop sequence } & \multirow{2}{*}{$\begin{array}{c}\text { Economic } \\
\text { yield }\left(\mathrm{kg} \mathrm{ha}^{-1}\right)\end{array}$} & \multirow{2}{*}{$\begin{array}{l}\text { Total revenue } \\
(\text { US } \$)^{-1}\end{array}$} & \multicolumn{3}{|c|}{ Cost of production (US\$) ha $\mathrm{ha}^{-1}$} & \multirow{2}{*}{ Total cost } & \multirow{2}{*}{ Net revenue } & \multirow{2}{*}{$\begin{array}{l}\text { Return on } \\
\text { investment }\end{array}$} \\
\hline & & & Land & Input & Labour & & & \\
\hline \multicolumn{9}{|l|}{ (a) Crops in the sequence } \\
\hline${ }^{1}$ Cassava & 31,000 & 2545.1 & 41.7 & 41.7 & 635.0 & 718.4 & 1826.7 & 254 \\
\hline${ }^{2}$ Pigeonpea & 1,870 & 623.3 & 41.7 & 8.3 & 221.5 & 271.5 & 351.8 & 130 \\
\hline${ }^{3}$ Mucuna-maize-mucuna & 2,016 & 365.1 & 41.7 & 41.7 & 247.4 & 330.8 & 34.3 & 10 \\
\hline${ }^{4}$ Cowpea-maize-cowpea & $2,536^{*}(1,230)$ & 1079.0 & 41.7 & 106,1 & 475.1 & 622.9 & 456.1 & 73 \\
\hline${ }^{5}$ Maize-maize-maize & 3,287 & 595.2 & 41.7 & 36.1 & 386.1 & 463.8 & 456.1 & 28 \\
\hline${ }^{6}$ Speargrass fallow & 0 & 0 & 41.7 & 0 & 0 & 41.7 & -41.7 & -100 \\
\hline \multicolumn{9}{|l|}{$\begin{array}{l}\text { (b) Maize after crop sequence } \\
\text { with } \mathrm{N} \text { application }\end{array}$} \\
\hline CS 1 & 2,738 & 495.9 & 13.9 & 104.2 & 190.2 & 308.3 & 187.6 & 61 \\
\hline CS 2 & 2,974 & 538.5 & 13.9 & 104.2 & 196.5 & 314.6 & 223.9 & 71 \\
\hline CS 3 & 4,194 & 759.4 & 13.9 & 104.2 & 245.9 & 364.0 & 395.4 & 108 \\
\hline CS 4 & 2,331 & 422.1 & 13.9 & 104.2 & 177.0 & 295.1 & 127.0 & 43 \\
\hline CS 5 & 2,126 & 385.0 & 13.9 & 104.2 & 175.4 & 293.5 & 91.4 & 31 \\
\hline CS 6 & 2,848 & 515.7 & 13.9 & 104.2 & 224.4 & 342.5 & 173.3 & 51 \\
\hline \multicolumn{9}{|l|}{$\begin{array}{l}\text { (c) Maize after crop sequence } \\
\text { without } \mathrm{N} \text { application }\end{array}$} \\
\hline CS 1 & 3,000 & 543.2 & 13.9 & 13.9 & 175.6 & 203.4 & 339.8 & 167 \\
\hline CS 2 & 2,423 & 438.8 & 13.9 & 13.9 & 165.5 & 193.3 & 245.5 & 127 \\
\hline CS 3 & 2,961 & 537.7 & 13.9 & 13.9 & 209.7 & 237.5 & 300.2 & 126 \\
\hline CS 4 & 1,772 & 302.8 & 13.9 & 13.9 & 155.2 & 183.0 & 119.8 & 66 \\
\hline CS 5 & 1,380 & 249.9 & 13.9 & 13.9 & 153.0 & 180.7 & 69.1 & 38 \\
\hline CS 6 & 1,048 & 189.8 & 13.9 & 13.9 & 173.7 & 200.9 & -11.1 & -6 \\
\hline
\end{tabular}

${ }^{1} \mathrm{US} \$ 82.1 \mathrm{t}^{-1}$

${ }^{2} \mathrm{US} \$ 333.3 \mathrm{t}^{-1}$.

${ }^{3} \mathrm{US} \$ 181.1 \mathrm{t}^{-1}$ for maize.

${ }^{4}$ US $\$ 337.5 \mathrm{t}^{-1}$ for cowpea and US\$181.1 $\mathrm{t}^{-1}$ for maize.

${ }^{5} \mathrm{US} \$ 181.1 \mathrm{t}^{-1}$ for maize.

${ }^{6} \mathrm{US} \$ 0$.

*Yield of maize (figure in brackets).

CS 1: cassava; CS 2: Pigeonpea; CS 3: Mucuna-maize-mucuna; CS 4: Cowpea-maize-cowpea; CS 5: Maize-maize-maize; CS 6: Speargrass fallow.

Source: [9].

transitional zone of Ghana where the crop is widely cultivated by farmers, migrant farmers prefer cowpea cultivation to pigeonpea cultivation although they acknowledge the superiority of the latter over the former in terms of soil fertility management and the yield of subsequent maize crop (Table 5). According to the migrants, the market for pigeonpea is not always readily available and return on investment is too slow. In addition, they were afraid that when they invest in the soil, they would not be allowed to reap the full benefit. Among the native farmers, female and male farmers differed in the cultivation of legumes such as pigeonpea and cowpea. Women farmers preferred pigeonpea over cowpea due to its role in food security as well as its low labour requirement [12]. Male farmers preferred cowpea over pigeonpea because the market for cowpea is developed than that of pigeonpea.

Access of farmers to early maturing varieties is also another barrier to widespread adoption of the pigeonpea.
Although the late maturing indeterminate pigeonpea varieties have the higher potential to improve soil fertility than the early maturing varieties due to greater biomass production, farmers prefer the early maturing determinate varieties. Criteria farmers used for selecting varieties for planting included maturity, plant height (for ease of harvesting), tolerant to insects, plant architecture (prefer varieties with smaller plant canopy for ease of intercropping with yams), and seed size (bigger seed size is preferred). Amount of biomass and/litter falls and ability to improve soil fertility were not mentioned as criteria although farmers claimed that soil fertility was one of their major production challenges and that pigeonpea was one of the crops they used to improve the fertility of their soils. Although late maturing indeterminate pigeonpea varieties with woody stems are a potential source of fuel wood, farmers did not also include this in their selection criteria. This may be due to the fact that accessibility to fuel wood was not a major constraint in Wenchi. 
TABLE 5: Preferential ranking of different soil fertility management practices by native and migrant farmers in Wenchi.

\begin{tabular}{|c|c|c|c|c|c|c|c|c|}
\hline \multirow{3}{*}{ Management practice } & \multicolumn{8}{|c|}{ Ranking order* } \\
\hline & \multicolumn{4}{|c|}{ Natives } & \multicolumn{4}{|c|}{ Migrants } \\
\hline & $\begin{array}{l}\text { Asuoanoa } \\
N=10\end{array}$ & $\begin{array}{l}\text { Beposob } \\
N=5\end{array}$ & $\begin{array}{c}\text { Drobosoc } \\
N=7\end{array}$ & Average & $\begin{array}{l}\text { Asuoanod } \\
\quad N=6\end{array}$ & $\begin{array}{l}\text { Beposod } \\
N=6\end{array}$ & $\begin{array}{l}\text { Drobosoe } \\
N=5\end{array}$ & Average \\
\hline \multicolumn{9}{|l|}{ (a) Ranking by natives and migrants } \\
\hline Cassava & 1 & 1 & 1 & 1 & 2 & 2 & 1 & 1.7 \\
\hline Pigeonpea & 2 & 5 & 2 & 3 & 4 & 4 & 4 & 4 \\
\hline Mucuna/Maize/Mucuna & 7 & 6 & 4 & 5.7 & 5 & 6 & 6 & 5.6 \\
\hline Groundnut/Maize/Groundnut & 4 & 3 & 3 & 3.3 & 3 & 3 & 3 & 3 \\
\hline Cowpea/Maize/Cowpea & 3 & 2 & 5 & 3.3 & 1 & 1 & 2 & 1.3 \\
\hline Maize/Maize/Maize & 8 & 7 & 6 & 7 & 7 & 7 & 7 & 7 \\
\hline Cowpea/Cowpea/Cowpea & 5 & 4 & 7 & 5.3 & 6 & 5 & 5 & 5.3 \\
\hline Bush fallow & 6 & 8 & 8 & 7.3 & 8 & 8 & 8 & 8 \\
\hline (b) Ranking by female and male Bonos & $\begin{array}{c}\text { Females } \\
N=13\end{array}$ & $\begin{array}{c}\text { Males } \\
N=10\end{array}$ & & & & & & \\
\hline Cassava & 1 & 1 & & & & & & \\
\hline Pigeonpea & 2 & 3 & & & & & & \\
\hline Mucuna/Maize/Mucuna & 5 & 7 & & & & & & \\
\hline Groundnut/Maize/Groundnut & 3 & 4 & & & & & & \\
\hline Cowpea/Maize/Cowpea & 4 & 2 & & & & & & \\
\hline Maize/Maize/Maize & 8 & 8 & & & & & & \\
\hline Cowpea/Cowpea/Cowpea & 7 & 5 & & & & & & \\
\hline Bush fallow & 6 & 6 & & & & & & \\
\hline
\end{tabular}

${ }^{a}$ Consisted of 6 males and 4 females; ${ }^{\mathrm{b}}$ Consisted of 4 males and 1 female; ${ }^{\mathrm{c} C o n s i s t e d ~ o f ~} 6$ females and 1 male; ${ }^{\mathrm{d}}$ Dagarbas; ${ }^{\mathrm{e}}$ Walas.

*Each treatment was compared directly against the other until they were ranked from the highest to the lowest with 1 being the highest ranking and 8 being the lowest.

Source: [9].

During focus group discussions in the field, the farmers noted that the late maturing pigeonpea varieties had produced a lot of biomass and had higher litterfalls compared with the early maturing varieties. The farmers observed and commented on the greater litterfall from the late maturing varieties. They further stated that the greater production of biomass and the higher litterfall of the late maturing varieties would lead to better soil fertility improvement compared with the early maturing pigeonpea varieties. Despite their recognition of the soil fertility benefits of the late maturing varieties in improving soil fertility, the farmers did not include this as an important criterion for selecting which pigeonpea varieties to grow (Table 6). Mapfumo et al. [20] made a similar observation in Zimbabwe and suggested that pigeonpea is less likely to be adopted merely on the basis of its capacity to improve soil fertility. Farmers were thus interested in pigeonpea as a food security crop; soil fertility benefits were secondly. Farmers therefore opted for short duration/early maturing varieties which they could easily crop twice in a year. Thus the varieties ICPL 88039 and ICPL 88034 were the most preferred varieties because of their early maturity and high yielding. Although the variety ICPL 87091 was also preferred for their larger grain size, this variety was very susceptible to pod borers.
3.6. Implication of Large Scale Cultivation for System Sustainability. In addition to food uses, pigeonpea has outstanding soil improvement and conservation properties. The growth habit facilitates soil protection, as the canopy continues to expand during the dry season after the component crops in the mixed cropping have been harvested. Living and senesces pigeonpea leaves may offer protective cover for the soil during dry season to prevent the soil from drying out and reduce soil erosion and enhance rain percolation during the rainy season. In farming systems with minimal application of external inputs, management of organic resources plays a major role in maintaining both nutrient availability and soil organic matter [21]. In a cereal-based farming system as that found in the forest/savanna transitional agro-ecological zone of Ghana, where external input use is minimal, most recycling of $\mathrm{N}$ and $\mathrm{P}$ occurs through pigeonpea litterfall and green leafy biomass of pigeonpea incorporated into the soil after pigeonpea harvest [9]. Pigeonpea litterfall and green leafy biomass of pigeonpea are important sources of easily mineralizable $\mathrm{N}$ due to their high nitrogen (1.9 and 2.2\% for litterfall and green leafy biomass, resp.) leading to high decomposition rates. Thus, rotation involving pigeonpea within smallholder agriculture has the potential of maintaining a reasonable supply of $\mathrm{N}$ and $\mathrm{P}$ to cereal crops, 
TABLE 6: (a) Farmers' preference ranking and (b) farmers' criteria for selection of pigeonpea varieties for planting.

\begin{tabular}{|c|c|c|c|c|c|c|c|}
\hline \multirow{2}{*}{ (a) Variety } & \multicolumn{5}{|c|}{ Growth and yield characteristics } & \multicolumn{2}{|c|}{ Ranking and reasons for the rank } \\
\hline & $\begin{array}{l}\text { Flowering } \\
\text { pattern }\end{array}$ & $\begin{array}{c}\text { Maturity } \\
\text { period (days) }\end{array}$ & $\begin{array}{l}100 \text { grains } \\
\text { weight }(\mathrm{g})\end{array}$ & $\begin{array}{c}\text { Yield } \\
\text { (tons ha }{ }^{-1} \text { ) }\end{array}$ & Seed colour & Ranking & Reasons for the rank \\
\hline ICPL 88039 & Determinate & 125 & 10.1 & 1.6 & $\begin{array}{l}\text { Brownish } \\
\text { red }\end{array}$ & 1 & $\begin{array}{l}\text { Early maturing, short } \\
\text { plant height, could be } \\
\text { planted twice in a year }\end{array}$ \\
\hline ICPL 88034 & Determinate & 125 & 10.2 & 1.8 & $\begin{array}{l}\text { Brownish } \\
\text { red }\end{array}$ & 2 & $\begin{array}{l}\text { Early maturing, short } \\
\text { plant height, could be } \\
\text { planted twice in a year }\end{array}$ \\
\hline ICPL 87091 & Determinate & 125 & 12.1 & 1.1 & white & 3 & $\begin{array}{l}\text { Early maturing, short } \\
\text { plant height, could be } \\
\text { planted twice in a year }\end{array}$ \\
\hline Maruti & Indeterminate & 190 & 10.0 & NA & $\begin{array}{l}\text { Brownish } \\
\text { red }\end{array}$ & 4 & $\begin{array}{l}\text { Medium maturity, high } \\
\text { litter fall }\end{array}$ \\
\hline Lakshmi & Indeterminate & 196 & 10.2 & NA & $\begin{array}{l}\text { Brownish } \\
\text { red }\end{array}$ & 4 & High litter fall \\
\hline ICPL 96053 & Indeterminate & 195 & 10.1 & NA & $\begin{array}{l}\text { Brownish } \\
\text { red }\end{array}$ & 4 & High litter fall \\
\hline (b) Criteria & Ranking & & & & & & \\
\hline Maturity & 1 & & & & & & \\
\hline Number of plantings in a year & 2 & & & & & & \\
\hline Easy of harvesting (plant height) & 3 & & & & & & \\
\hline Easy of intercropping with yams & 4 & & & & & & \\
\hline Seed size & 5 & & & & & & \\
\hline
\end{tabular}

NA: not available.

Source: Adjei-Nsiah (unpublished results).

particularly maize considering the minimal use of external inputs in a maize-based farming system.

\section{Conclusion}

The paper shows the potential of pigeonpea in improving soil fertility in the smallholder farming systems particularly in a predominantly maize-based farming system as that found in Wenchi, Ghana. We have shown that the potential of pigeonpea in sustaining the productivity of predominantly maize-based farming system is due to its nutrient recycling properties as well as to its role in food security and flexibility in external input use and labour requirement. Soil fertility was apparently not a major criterion during varietal ranking by farmers suggesting that pigeonpea is less likely to be adopted merely on the basis of its capacity to improve soil fertility. Even when there was no strong market demand for pigeonpea, female farmers still integrated pigeonpea in their rotational system. Pigeonpea is largely a women's crop and therefore the attitude by men as major household decision makers has probably undermined its adoption in a predominantly maize based cropping system in Wenchi. Empowering women to make decision with respect to allocation of production resources may enhance a greater adoption of legumes. As more farmers resort to putting their land under pigeonpea instead of bush fallowing, pigeonpea cultivation could serve as an entry point for farming system sustainability. There is, however, the need to (i) introduce short duration pigeonpea varieties that will fit well in the predominantly mixed cropping systems of smallholder agriculture; (ii) evaluate the nutrient recycling capacities of different pigeonpea genotypes; (iii) develop crop rotation/sequencing and soil management options that can improve and/or sustain the productivity of pigeonpea through integrated soil fertility management (ISFM); (iv) design a range of social arrangements that will encourage investment in soil fertility through integration of pigeonpea in the farming system in a heterogeneous farming community like Wenchi, (v) develop use for pigeonpea in new cooking options and/or value added products.

\section{Acknowledgments}

The author is grateful to the two anonymous reviewers who reviewed an earlier version of this paper. Financial support towards this work provided by the Interdisciplinary Research and Education Fund (INREF) of Wageningen University and Research Centre, and The Netherlands and the Dutch Ministry for International Cooperation (DGIS) is gratefully acknowledged. The author also thanks the International Development Centre for funding the climate change adaption in Africa project through the University of Zimbabwe. 


\section{References}

[1] P. H. Nye and D. Stephen, "Soil fertility," in Agriculture and Landuse in Ghana, J. B. Wills, Ed., pp. 127-143, Oxford University Press, London, UK, 1962.

[2] H. Gerner, E. O. Asante, E. Owusu Benoah, and K. Marfo, Ghana Fertilizer Privatization Scheme. Private Sector Role and Public Sector Responsibility in Meeting Needs of Farmers, IFDCAfrica, Lome, Togo, 1995.

[3] P. A. Sanchez, "Soil fertility and hunger in Africa," Science, vol. 295, no. 5562, pp. 2019-2020, 2002.

[4] ISSER, The state of Ghana economy in 2004, University of Ghana, Legon, Ghana, 2005.

[5] H. B. Obeng, K. G. Erbyn, and E. O. Asante, "Fertilizer requirements and Use in Ghana," Consultancy Report, Tropical Agricultural Development Consultancy, Accra, Ghana.

[6] K. E. Giller, Nitrogen Fixation in Tropical Cropping Systems, CAB International, Wallingford, UK, 2nd edition, 2001.

[7] S. S. Snapp, R. B. Jones, E. M. Minja, J. Rusike, and S. N. Silim, "Pigeon Pea for africa: a versatile vegetable—and more," HortScience, vol. 38, no. 6, pp. 1073-1079, 2003.

[8] S. Adjei-Nsiah, C. Leeuwis, K. E. Giller et al., "Land tenure and differential soil fertility management practices among native and migrant farmers in Wenchi, Ghana: implications for interdisciplinary action research," NJAS-Wageningen Journal of Life Sciences, vol. 52, no. 3-4, pp. 331-348, 2004.

[9] S. Adjei-Nsiah, T. W. Kuyper, C. Leeuwis, M. K. Abekoe, and K. E. Giller, "Evaluating sustainable and profitable cropping sequences with cassava and four legume crops: effects on soil fertility and maize yields in the forest/savannah transitional agro-ecological zone of Ghana," Field Crops Research, vol. 103, no. 2, pp. 87-97, 2007.

[10] D. Hounkonnou, D. K. Kossou, T. W. Kuyper et al., "Convergence of sciences: the management of agricultural research for small-scale farmers in Benin and Ghana," NJAS-Wageningen Journal of Life Sciences, vol. 53, no. 3-4, pp. 343-367, 2006.

[11] P. Mapfumo, F. Matambanengwe, R. Chikowo et al., "Farmers' perceptions lead to experimentation?" LEISA Magazine, vol. 24, 2008.

[12] S. Adjei-Nsiah, C. Leeuwis, O. Sakyi-Dawson, K. E. Giller, and T. W. Kuyper, "Exploring diversity among farmers for orienting inter-disciplinary action research on cropping system management in Wenchi, Ghana: the significance of time horizons," International Journal of Agricultural Sustainability, vol. 5, pp. 176-194, 2007.

[13] S. Adjei-Nsiah, "Evaluating cropping sequences with cassava and three grain legume crops: effects on soil fertility and maize yields in the semi-deciduous forest zone of Ghana," Journal of Soil Science And Environmental Management, vol. 4, no. 1, 2012.

[14] S. Adjei-Nsiah, Cropping systems, land tenure and social diversity in Wenchi, Ghana: implication for soil fertility management [Ph.D. thesis], Wageningen University, The Netherlands, 2006.

[15] A. A. Yusuf, R. C. Abaidoo, E. N. O. Iwuafor, O. O. Olufajo, and N. Sanginga, "Rotation effects of grain legumes and fallow on maize yield, microbial biomass and chemical properties of an Alfisol in the Nigerian savanna," Agriculture, Ecosystems and Environment, vol. 129, no. 1-3, pp. 325-331, 2009.

[16] S. Recous, D. Robin, D. Darwis, and B. Mary, "Soil inorganic N availability: effect on maize residue decomposition," Soil Biology and Biochemistry, vol. 27, no. 12, pp. 1529-1538, 1995.
[17] W. D. Sakala, G. Cadisch, and K. E. Giller, "Interactions between residues of maize and pigeonpea and mineral $\mathrm{N}$ fertilizers during decomposition and N mineralization," Soil Biology and Biochemistry, vol. 32, no. 5, pp. 679-688, 2000.

[18] K. E. Giller and G. Cadisch, "Future benefits from biological nitrogen fixation: an ecological approach to agriculture," Plant and Soil, vol. 174, no. 1-2, pp. 255-277, 1995.

[19] N. Ae, J. Arihara, K. Okada, T. Yoshihara, and C. Johansen, "Phosphorus uptake by pigeon pea and its role in cropping systems of the Indian subcontinent," Science, vol. 248, no. 4954, pp. 477-480, 1990.

[20] P. Mapfumo, B. M. Campbell, S. Mpepereki, and P. Mafongoya, "Legumes in soil fertility management: the case of pigeonpea in smallholder farming systems of Zimbabwe?" African Crop Science Journal, vol. 9, no. 4, pp. 629-644, 2001.

[21] C. A. Palm, K. E. Giller, P. L. Mafongoya, and M. J. Swift, "Management of organic matter in the tropics: translating theory into practice," Nutrient Cycling in Agroecosystems, vol. 61, no. 1-2, pp. 63-75, 2001. 


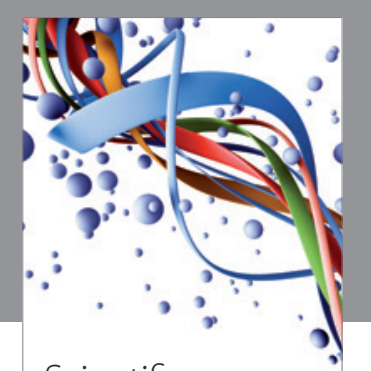

Scientifica
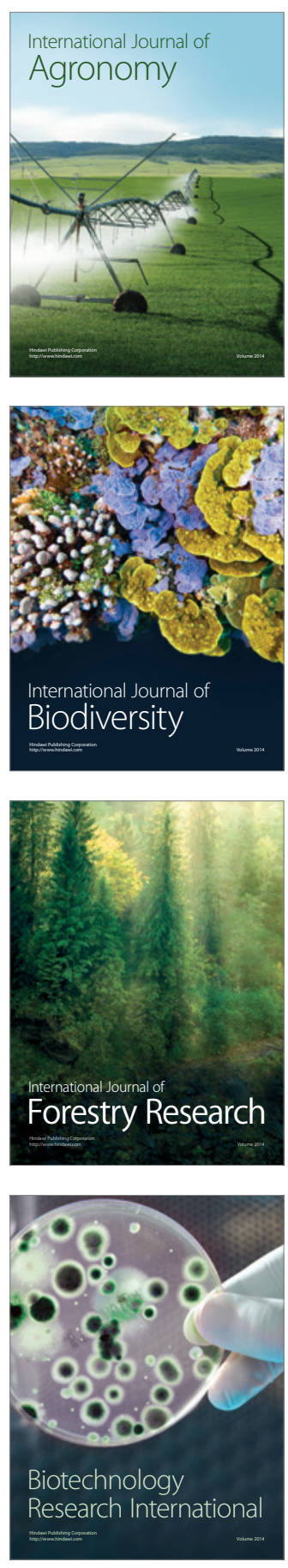
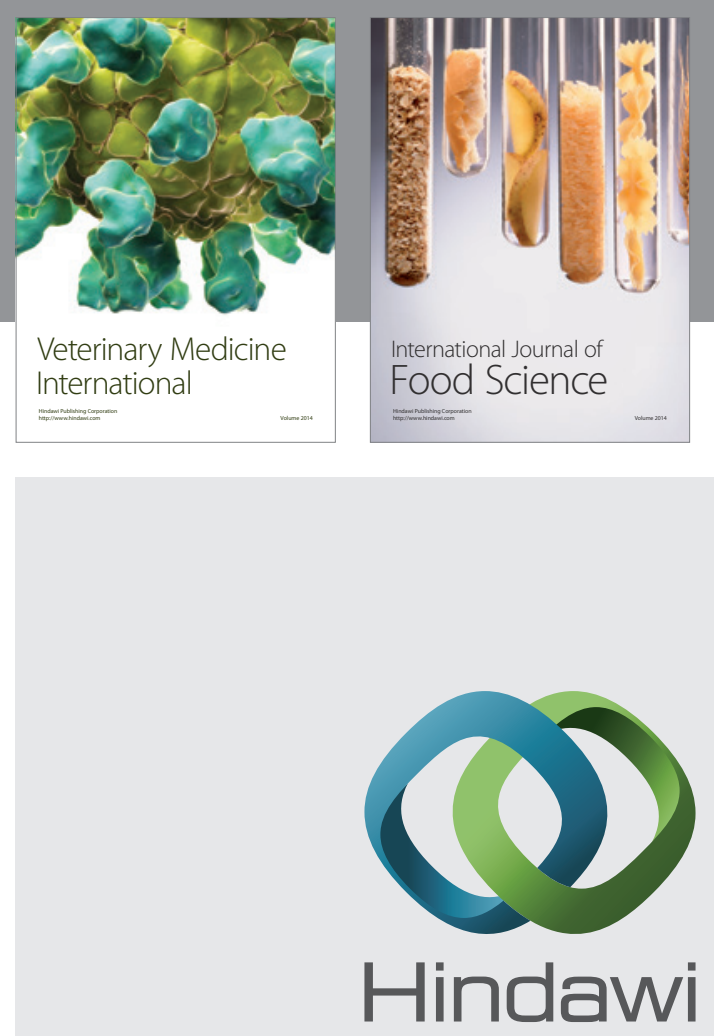

Submit your manuscripts at

http://www.hindawi.com
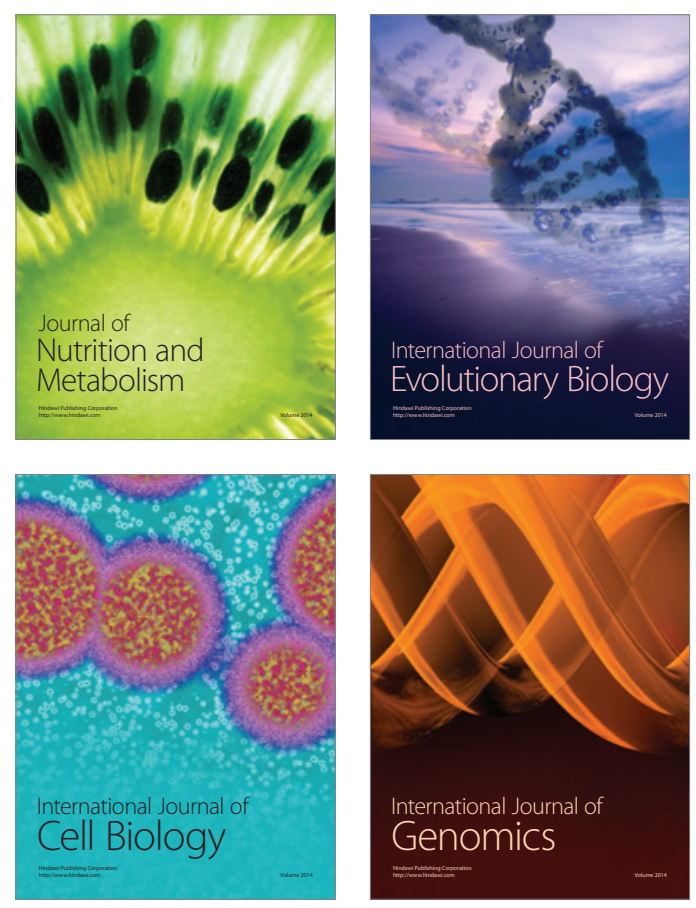
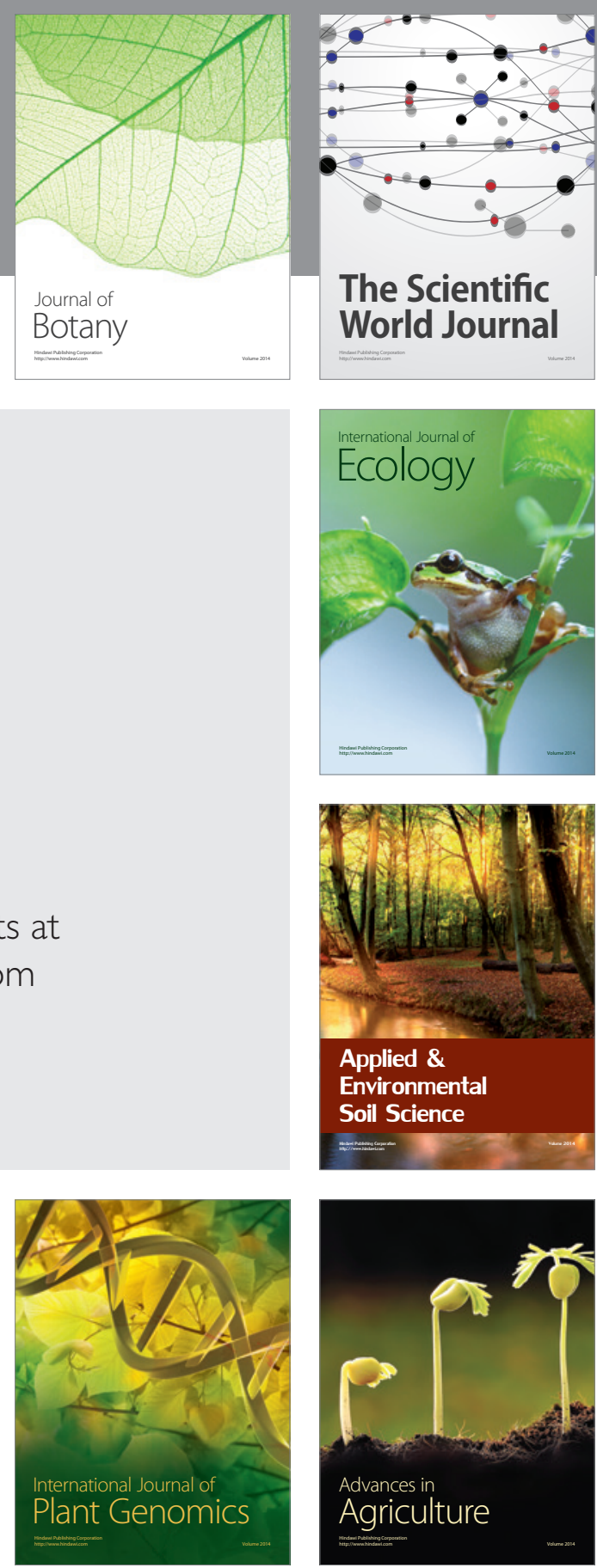

The Scientific World Journal
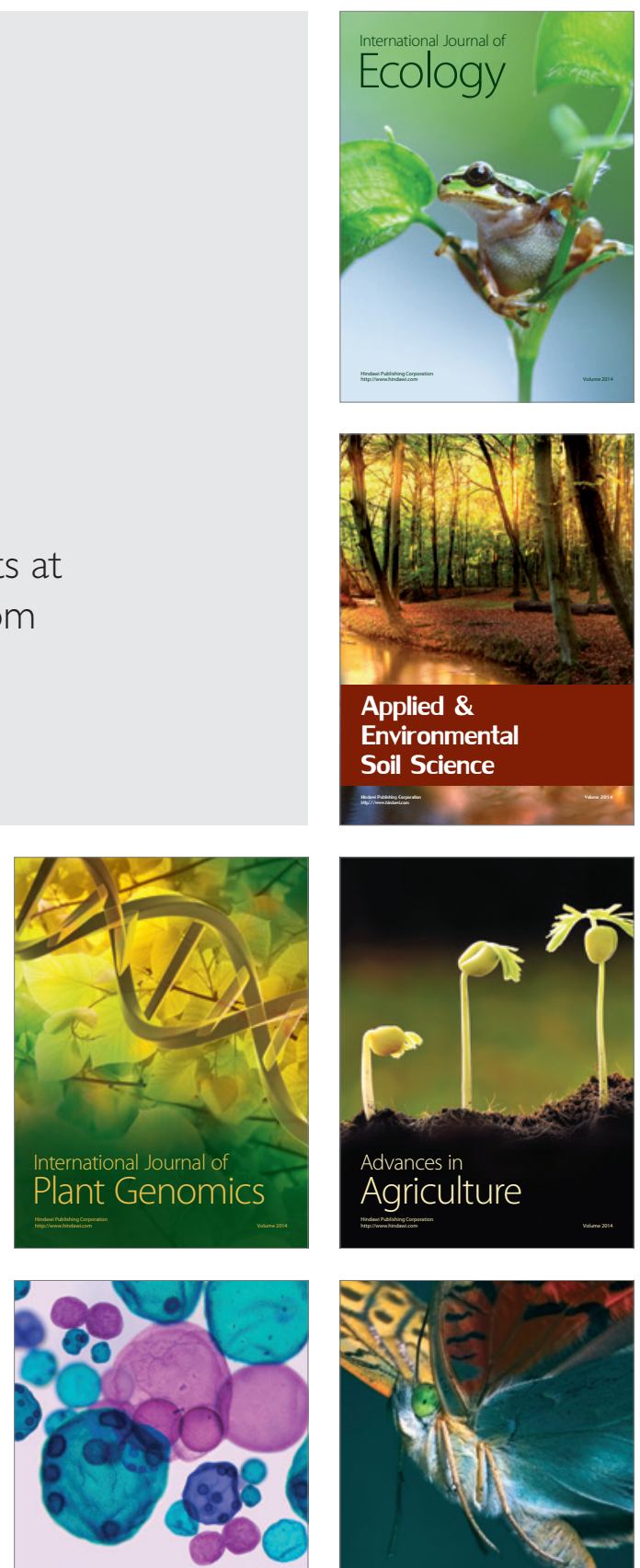

International Journal of Microbiology

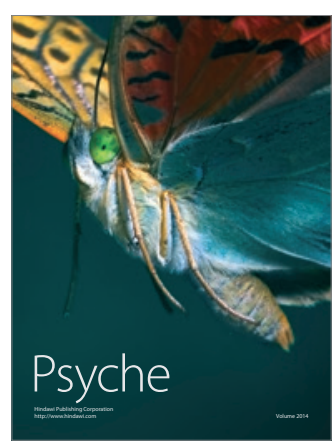

